\title{
THE IMPLEMENTATION OF TEACHING MATERIAL BASED ON STEM IN FLUID FOR BIOLOGY STUDENT
}

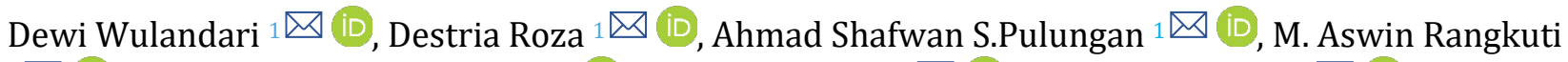

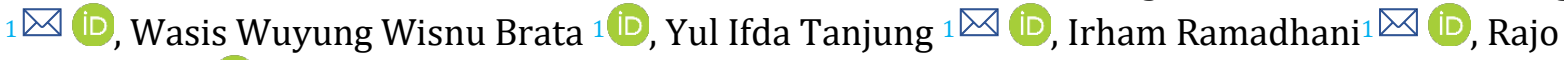 \\ Hasim $L_{1} \bowtie$ (iD)
}

${ }^{1}$ Mathematics and Natural Sciences Faculty, Universitas Negeri Medan, Jalan Willem Iskandar Pasar V Medan State 20221, North Sumatera, Indonesia
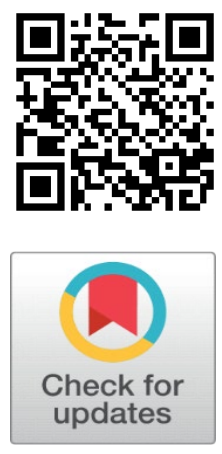

Received 17 January 2022

Accepted 20 February 2022

Published 04 March 2022

\section{Corresponding Author}

Dewi Wulandari,

wulandaridewi@unimed.ac.id

DOI

10.29121/granthaalayah.v10.i2.2022 .4507

Funding: This research received no specific grant from any funding agency in the public, commercial, or not-for-profit sectors.

Copyright: (C) 2022 The Author(s). This is an open access article distributed under the terms of the Creative Commons Attribution License, which permits unrestricted use, distribution, and reproduction in any medium, provided the original author and source are credited.

\section{ABSTRACT}

In this time, every student will need to know interdisciplinary knowledge. The purpose of this research is to develop a teaching material collaborating the understanding of physics concept about fluid topic and its application in biology based on Science, Technology, Engineering, and Mathematics (STEM) to enhance scientific literacy skills of students. The developed teaching material has passed a validation process including content, the designed problems/questions for each subtopic and from the STEM aspect. The basic competencies that have been set are generally related to understanding the concept of static and dynamic fluid and their application in biology. For static fluid emphasizes on the physics concept in terms of pressure, Pascal's principle, buoyancy, and surface tension. Understanding these concepts are then used to analyze the phenomena of worm movement, fish buoyancy, water transport in plants, Marangoni propulsion in Microvelia insects. For dynamic fluid, it emphasizes on the concept physics such as the Bernoulli equation, viscosity, Poiseuille's law, laminar and turbulent flow. Understanding these concepts are then used to analyze the phenomenon of blood flow in humans. While for STEM, it focuses on the technique of dilating narrow blood vessels. To determine the effectiveness of the developed teaching materials, $\mathrm{N}$ gain analysis and student response tests were then carried out. According to $\mathrm{N}$ gain test, it shows an increase in scientific literacy by 0.48 due to the use of this teaching material and finally from the student response test, it shows that the developed teaching materials are feasible for use as a learning source for students.

Keywords: Teaching Material, Stem, Fluids, Interdisciplinary

\section{INTRODUCTION}

Students' scientific literacy skills are represented in the fields of mathematics, physics, chemistry, and biology. Unfortunately, the results of the 2018 Pisa show that the literacy ability of Indonesian students has decreased compared to the results of the 2015 Pisa test. A thorough understanding of science can be realized by accommodating cross-disciplinary fields, for example by integrating basic physics concepts with biology in a STEM-based teaching material. The "integration of math, technology and engineering should be used to support the learning of a science concept" Hilton and Jackie (2018).

In the future, every student in a certain academic field needs to know important knowledge from other academic fields which creates interdisciplinary programs that are very useful to answer the challenges over the years. In sciencebased faculties such as mathematics and natural sciences faculty and also engineering faculty, physics is a prerequisite course in the first year of study. 
All students are required to take the Basic Physics course as their compulsory course. However, several studies show that students who are not majoring in physics consider that physics is not very important for them Klymkowsky et al. (2003), Nicoll (2001). These results are also in accordance with the several research in Indonesia that students who are not majoring in physics find that the material in Physics astonish because the knowledge that they have is not related to their field Toto and Yulisma (2017), Damayanti and Perdana (2016).

Physics is an essential science because the concepts in physics are used to explain phenomena in daily life. Engineering, medicine, and computer science are some of the many branches of science that use the principles of physics Keevil (2012), Serway and Jewett (2018), Maris et al. (2010). The use of Physics is very fundamental for the development of sciences that most people are studying Frankel (2011), Koonin (2018).

There are a numerous number of students take science courses at colleges and universities in Indonesia, but students who are interested in taking physics at university are only limited to analyse mathematical equations algebraically or calculus which are not support in understanding a whole science. Thus, it is important to develop interdisciplinary courses to improve science literacy for student.

At first glance reading physics and biology teaching materials can give the impression that these two fields of science are very different. These differences include the system being studied, the behaviour of the system, the type of measurement performed, and the role of mathematics in each area. In basic physics teaching materials, many equations are found to explain a phenomenon. While the basic biology teaching materials describe many diagrams of systems, structures, and biological processes, but only a few equations.

Although physics and biology seem very different, both disciplines are based on the process of observation and experimentation to explain or make predictions about nature. For this reason, it is necessary to develop teaching materials by combining these two disciplines so that they can fully explain natural phenomena by helping students achieve an integrated and coherent understanding, so that it is possible to encourage them in understanding a whole natural phenomenon.

In physics, a natural phenomenon can be explain using several formulas mathematically. Thus, using these formulas, it can make predictions. For example, in kinematics and dynamics topics, variables such as position, velocity, force, and energy can be calculated accurately with various initial conditions, so that the value of these variables can be predicted for a changing system. While in the field of biology, mathematical equations are very rarely used which represents that the goal in biology is not to make predictions but to explain the relationship between the structure and function of an object of observation. Biological science tends to prove the reasoning of a hypothesis. But some topics in biology can also be understood with predictions as had been discovered by Gregor Mendel in explaining that parents pass traits to their offspring through an object called a gene. Gregor Mendel's predictions continue to evolve, for example in plant breeding, which is also supported by experiments that challenge biologists to search for the substance in cells that conveys genetic information, called DNA.

\section{MATERIALS AND METHODS}

This research is part of Research and Development (R\&D) type. The developed teaching material in this research is based on STEM integrating the physics concept 
and its application for Biology student. The analysed scope of materials in this research are static and dynamic fluids.

In general, the main activities in this research consist of five steps described as follows: The first step was tributed for analysing needs consisting of literature studies (journal analysis) and observation. Establishing plans and goals were carried out in the second step. The activities in this stage included analysing basic competencies and formulating research instruments. The third step was dedicated for developing the initial product of teaching material consisting of arranging the content corresponding for static and dynamic fluids including their applications in biology and the preparation of STEM material is also carried out in this stage. This stage also addressed to design problems or question in order to measure the achievement of established basic competencies. The fourth was tributed to the validation process. And the last step was accommodated to test the product to a class of biology student consisting of 40 biology students. This class is used to implement and test the teaching material that has been developed. The teaching material has been completed with the test instrument and the test instrument was tested to the student. The implementation process was applied in the class with the following steps: (1) learning process activities using the developed teaching material; (2) discussing physical concept correlated to biology; (3) discussing solution for selected problem; (4) solving problems (test instrument).

The feasibility of teaching material is analysed in three categories, namely: the content eligibility, the use of language and the technical appearance/layout. The data analysis was conducted based on the questionnaire of feasibility level from the National Education Standards Agency / Badan Standard Nasional Pendidikan (BSNP) questionnaire. While to measure the effectiveness of the developed teaching materials also is constructed a test instrument consisting of 15 questions. This instrument is also validated by experts. The fact, the research outcome is prioritized on cognitive domain. The cognitive test is constructed to examine the of physics concept in terms of fluids related to in biology. The data analysis was shown in terms of N-Gain.

Due to those the developed teaching materials is based on STEM, thus the validation of STEM aspect also is conducted. As users, students are also giving feedback to the developed teaching materials in the form of questionnaire.

The data obtained from validation process will be analysed for each category. Each category consists of several aspects that are assessed. Each aspect is assessed using a Likert scale using numbers 1, 2, 3 and 4 . The score of each aspect is obtained from the total score divided by the maximum score. The assessment results are then analysed using the following table Akbar (2013).

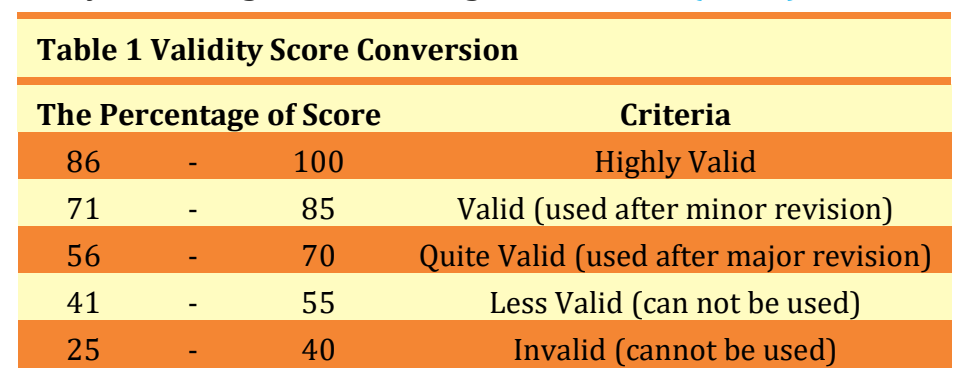

The effectiveness of teaching material can be measured from the normalized gain (N-Gain). The data are obtained from the score of pre-test and post-test. The NGain is calculated using the following formula: 


$$
N-\text { Gain }=\frac{S_{\text {post }}-S_{\text {pre }}}{S_{\text {maks }}-S_{\text {pre }}}
$$

Where $S_{\text {post }}$ is post-test score, $S_{\text {pre }}$ is pre-test score and $S_{\text {maks }}$ is ideally maximum value Hake (2002). The criteria of $\mathrm{N}$-Gain value are represented in the following table

\begin{tabular}{|ccc|}
\hline \multicolumn{2}{|c|}{ Table 2 The Criteria of $\mathbf{N}$-Gain Value } & \\
\hline Average $\mathbf{N}$-Gain Value & Criteria & Level of Effectiveness \\
$\bar{g} \geq 0.70$ & High & Effective \\
$0.30 \leq \bar{g} \leq 0.70$ & Medium & Quite Effective \\
$\bar{g}<0.70$ & Low & Less Effective \\
\hline
\end{tabular}

\section{RESULTS AND DISCUSSIONS}

The basic competencies that have been set are generally related to understanding the concept of static and dynamic fluid and their application in biology and those were listed in the following table

\begin{tabular}{|c|c|}
\hline Static Fluid & Dynamic Fluid \\
\hline $\begin{array}{l}\text { Students can understand static fluid properties such } \\
\text { as pressure, buoyancy, surface tension. }\end{array}$ & $\begin{array}{l}\text { Students can understand the Bernoulli } \\
\text { equation, viscosity and Poiseuille's law, } \\
\text { turbulent flow, and its application to } \\
\text { human blood circulation. }\end{array}$ \\
\hline $\begin{array}{l}\text { Students can analyze the application of Pascal's } \\
\text { principles to zoology, understand how earthworms } \\
\text { can move. }\end{array}$ & $\begin{array}{l}\text { Students can understand the circulation of } \\
\text { blood flow in the body, understand the } \\
\text { factors that affect fluid flow, analyze the } \\
\text { function of the heart, blood vessels. }\end{array}$ \\
\hline $\begin{array}{l}\text { Students can analyze the power required to float and } \\
\text { its application to fish. }\end{array}$ & $\begin{array}{l}\text { Students are able to understand blood } \\
\text { pressure and how to measure blood } \\
\text { pressure in the body. }\end{array}$ \\
\hline $\begin{array}{l}\text { Students can understand the concept of surface } \\
\text { tension, capillarity, and its application to the ability } \\
\text { of roots to pull water up, understand the use of } \\
\text { surface tension in insects as a driving force } \\
\text { (Marangoni propulsion). }\end{array}$ & $\begin{array}{c}\text { Students can analyze the regulation of } \\
\text { blood flow in the body, the energy of } \\
\text { blood flow, the causes of turbulent blood } \\
\text { flow, the power generated from the heart } \\
\text { pump }\end{array}$ \\
\hline
\end{tabular}

The validation in terms of content of teaching materials consist of the content eligibility, the use of language and the technical appearance/layout. The developed teaching materials are validated by 2 expert lectures. The result of validation process was showed in the Table 4 as follows

Table 4 The validity of teaching material content

\begin{tabular}{|cccccc}
\hline Assessed components & \multicolumn{3}{c}{ Score } & Percentage of Average Score & Criteria \\
\hline & V-1 & V-2 & & \\
\hline The content eligibility & 36 & 37 & 82.95 & Valid \\
\hline The use of language & 37 & 38 & 78.13 & Valid \\
\hline The technical appearance/layout & 30 & 29 & 81.94 & Valid \\
\hline
\end{tabular}


The result show that all analysed components of teaching material are valid. The validators also give feedback and selected feedbacks are listed in the following table

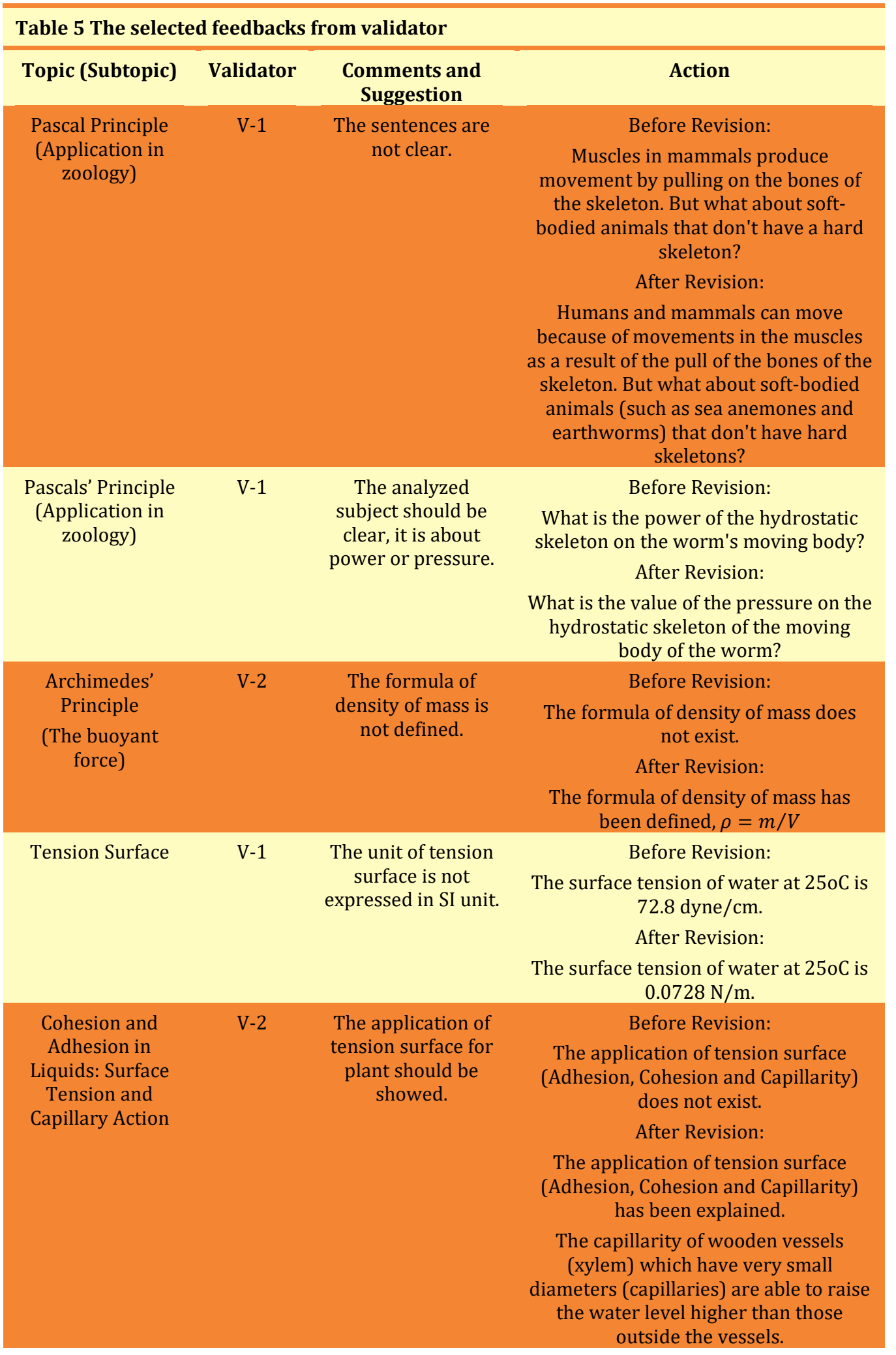


The Implementation of Teaching Material Based on Stem in Fluid for Biology Student

\begin{tabular}{|c|c|c|c|}
\hline $\begin{array}{l}\text { Flow rate (The } \\
\text { equation of } \\
\text { continuity) }\end{array}$ & $\mathrm{V}-2$ & $\begin{array}{l}\text { The application in } \\
\text { terms of flow rate in } \\
\text { biology should be } \\
\text { explained clearly }\end{array}$ & $\begin{array}{l}\text { Before Revision: } \\
\text { The application flow rate in biology } \\
\text { does not exist. } \\
\text { After Revision: } \\
\text { The equation of continuity is used to } \\
\text { calculate flow speed and vessel } \\
\text { diameter: branching in the } \\
\text { cardiovascular system }\end{array}$ \\
\hline $\begin{array}{l}\text { Viscosity and } \\
\text { Poiseuille's law }\end{array}$ & $\mathrm{V}-1$ & $\begin{array}{l}\text { Viscosities of several } \\
\text { fluids should be } \\
\text { showed. }\end{array}$ & $\begin{array}{c}\text { Before Revision: } \\
\text { The value of viscosities for selected } \\
\text { fluids do not exist. } \\
\text { After Revision: } \\
\text { The viscosities of some fluids are listed } \\
\text { in table }\end{array}$ \\
\hline $\begin{array}{l}\text { Circulation of the } \\
\text { blood }\end{array}$ & V-1 & $\begin{array}{l}\text { The function of } \\
\text { hearth is not defined } \\
\text { clearly. }\end{array}$ & $\begin{array}{l}\text { Before Revision: } \\
\text { The function of hearth does not exist. } \\
\text { After Revision: } \\
\text { The function of hearth is explained } \\
\text { clearly. }\end{array}$ \\
\hline Blood pressure & $\mathrm{V}-2$ & $\begin{array}{l}\text { The measurement of } \\
\text { blood pressure } \\
\text { should be explained. }\end{array}$ & $\begin{array}{c}\text { Before Revision: } \\
\text { The measurement of blood pressure } \\
\text { does not exist. } \\
\text { After Revision: } \\
\text { The measurement of blood flow is } \\
\text { explained clearly. }\end{array}$ \\
\hline
\end{tabular}

The designed instrument tests are used to measure the student outcomes after they use this teaching materials. The validity of instrument test is showed in the Table 6.

Table 6 The validity of instrument test

\begin{tabular}{|c|c|c|c|c|c|c|c|c|}
\hline \multirow{3}{*}{$\begin{array}{c}\text { Assessed } \\
\text { Components }\end{array}$} & \multicolumn{8}{|c|}{ The Percentage of Average Score } \\
\hline & \multicolumn{8}{|c|}{ Question Number } \\
\hline & 1 & 2 & 3 & 4 & 5 & 6 & 7 & 8 \\
\hline $\begin{array}{l}\text { Material } \\
\text { coverage }\end{array}$ & 100 & 96.87 & 96.87 & 93.75 & 100 & 100 & 100 & 93.75 \\
\hline $\begin{array}{l}\text { The use of } \\
\text { language }\end{array}$ & 100 & 100 & 100 & 100 & 100 & 100 & 100 & 100 \\
\hline The construct & 100 & 100 & 95.83 & 91.66 & 100 & 100 & 95.83 & 95.83 \\
\hline $\begin{array}{l}\text { The average } \\
\text { percentage of } \\
\text { all } \\
\text { components }\end{array}$ & 100 & 98.95 & 97.57 & 95.14 & 100 & 100 & 98.61 & 96.53 \\
\hline $\begin{array}{l}\text { Criteria } \\
\text { Validation }\end{array}$ & $\begin{array}{l}\text { Highly } \\
\text { Valid }\end{array}$ & $\begin{array}{l}\text { Highly } \\
\text { Valid }\end{array}$ & $\begin{array}{l}\text { Highly } \\
\text { Valid }\end{array}$ & $\begin{array}{l}\text { Highly } \\
\text { Valid }\end{array}$ & $\begin{array}{l}\text { Highly } \\
\text { Valid }\end{array}$ & $\begin{array}{l}\text { Highly } \\
\text { Valid }\end{array}$ & $\begin{array}{l}\text { Highly } \\
\text { Valid }\end{array}$ & Highly Valid \\
\hline \multirow[t]{3}{*}{$\begin{array}{l}\text { Assessed } \\
\text { Components }\end{array}$} & \multicolumn{8}{|c|}{ The Percentage of Average Score } \\
\hline & \multicolumn{8}{|c|}{ Question Number } \\
\hline & 9 & 10 & 11 & 12 & 13 & 14 & 15 & \\
\hline $\begin{array}{l}\text { Material } \\
\text { coverage }\end{array}$ & 100 & 100 & 96.87 & 93.75 & 100 & 96.87 & 100 & $\begin{array}{l}\text { Material } \\
\text { coverage }\end{array}$ \\
\hline $\begin{array}{l}\text { The use of } \\
\text { language }\end{array}$ & 100 & 100 & 100 & 97.92 & 100 & 100 & 100 & $\begin{array}{l}\text { The use of } \\
\text { language }\end{array}$ \\
\hline The construct & 100 & 100 & 100 & 100 & 100 & 100 & 100 & The construct \\
\hline
\end{tabular}



and Rajo Hasim L

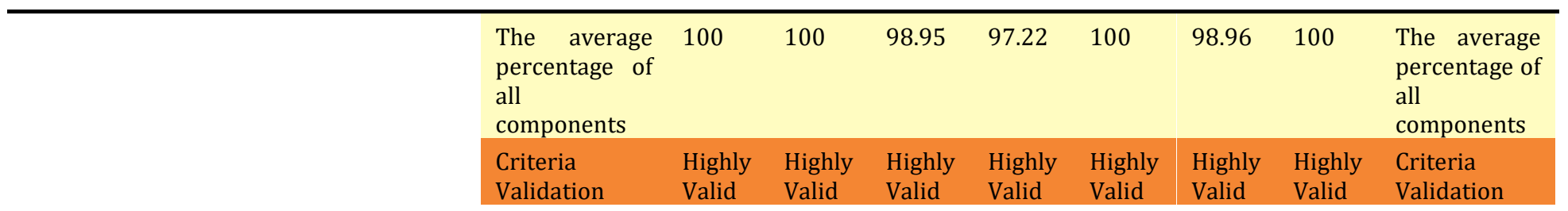

The result shows that the fifteen questions are valid. The validators also give feedback to the questions. Some revisions from the validator are outlined in the following table.

\begin{tabular}{|c|c|c|c|}
\hline $\begin{array}{l}\text { Question } \\
\text { Number }\end{array}$ & Validator & $\begin{array}{l}\text { Comments and } \\
\text { Suggestion }\end{array}$ & Action \\
\hline \multirow[t]{4}{*}{1} & \multirow[t]{4}{*}{1,2} & \multirow{4}{*}{$\begin{array}{l}\text { The basic } \\
\text { competencies } \\
\text { should be revised }\end{array}$} & Before revision: \\
\hline & & & $\begin{array}{l}\text { Students understand the concept of buoyancy } \\
\text { and its applications. }\end{array}$ \\
\hline & & & After Revision: \\
\hline & & & Students apply concept of buoyancy in biology. \\
\hline \multirow[t]{4}{*}{4} & \multirow[t]{4}{*}{2} & \multirow{4}{*}{$\begin{array}{l}\text { The indicator } \\
\text { should be revised }\end{array}$} & Before revision: \\
\hline & & & $\begin{array}{l}\text { Mathematical equation of pressure difference } \\
\text { between head and feet. }\end{array}$ \\
\hline & & & After Revision: \\
\hline & & & $\begin{array}{l}\text { Formula of hydrostatic pressure, blood flows } \\
\text { from head to feet, thus h is distance from head } \\
\text { to feet. }\end{array}$ \\
\hline \multirow[t]{4}{*}{7} & \multirow[t]{4}{*}{1} & \multirow{4}{*}{$\begin{array}{l}\text { The arranged } \\
\text { sentences of } \\
\text { question do not } \\
\text { clear, should be } \\
\text { revised. }\end{array}$} & Before revision: \\
\hline & & & $\begin{array}{l}\text { Some insects like Microvelia can not only stand } \\
\text { on water but can also use surface tension as a } \\
\text { driving force. Try to explain that it is the } \\
\text { Marangoni locomotion that the Microvelia } \\
\text { insects use as a driving force! }\end{array}$ \\
\hline & & & After Revision: \\
\hline & & & $\begin{array}{l}\text { Some insects like Microvelia can not only stand } \\
\text { on water but can also use surface tension as a } \\
\text { driving force. How mechanism Microvelia } \\
\text { insects can use the Marangoni propulsion as a } \\
\text { driving force? (Note: Marangoni propulsion is a } \\
\text { driving force obtained with utilizing surface } \\
\text { tension) }\end{array}$ \\
\hline \multirow[t]{4}{*}{9} & \multirow[t]{4}{*}{2} & \multirow{4}{*}{$\begin{array}{l}\text { The basic } \\
\text { competencies } \\
\text { should be revised }\end{array}$} & Before revision: \\
\hline & & & Students understand the pressure concept. \\
\hline & & & After Revision: \\
\hline & & & $\begin{array}{l}\text { Students apply the pressure concept to } \\
\text { intravenous infusion. }\end{array}$ \\
\hline \multirow[t]{4}{*}{14} & \multirow[t]{4}{*}{2} & \multirow{4}{*}{$\begin{array}{l}\text { The basic } \\
\text { competencies } \\
\text { should be revised }\end{array}$} & Before revision: \\
\hline & & & Students understand blood flow. \\
\hline & & & After Revision: \\
\hline & & & Students analyze how blood flows in body. \\
\hline
\end{tabular}

In this research, the teaching materials has developed based on STEM. A discipline of science, mathematics, engineering, or technology is featured in this teaching materials discuss about how to dilate narrow blood vessels. The fact shows that one of the diseases that claimed many victims is coronary heart disease. This 
disease is caused by narrowing of blood vessels. Blood vessels function to supply blood and oxygen to the heart muscle. If these vessels narrow, the supply of blood and oxygen can be cut off, resulting in a heart attack. One of the factors that causes this narrowing of blood vessels is an unhealthy lifestyle, for example, smoking habits, lack of exercise, consuming high cholesterol foods, and foods with high sugar levels. With the development of technology, this narrowing of blood vessels can be addressed by placing a ring or stent on the narrowed blood vessel. With this ring installation method, the narrowed blood vessels will widen so that the heart returns to normal in supplying blood and oxygen. The procedure for placing a heart ring is known as Percutaneous Transluminal Coronary Angioplasty (PTCA). The installation of the stent is permanent. Therefore, the material for making this stent must be safe for the body. The beginning of the development of making this ring or stunt made of metal. But many patients worry about this metal ring because it has to stay in the body for long life. However, with the development of technology, the heart ring material can dissolve in a certain period of time. The stent material that can dissolve in the body is called the Bioresorbable Vascular Scaffold (BVS). From engineering aspect that the stent can be designed in the form of a small tube that is arranged like a net. Mathematics aspect shows that the problem caused by narrowing blood vessel can be explained clearly through the Bernoulli equation. Blood flowing through a narrow area will be accelerated. For example, if the radius of the artery narrows by a factor of 3, the area will decrease by a factor of 9 resulting in 9 times increase in velocity. This condition will cause the kinetic energy to increase by 81 times. This increase in kinetic energy affects blood pressure to maintain a high flow rate. Potential energy is converted into kinetic energy and consequently the blood pressure in the area of constriction will decrease. For example, if in a normal artery the velocity of blood flow is $50 \mathrm{~cm} / \mathrm{s}$, then when blood enters a narrowed area, where the area of the area is reduced by a factor of 9 , then the velocity of blood flow becomes $450 \mathrm{~cm} / \mathrm{s}$. Simultaneously, the pressure was reduced by about 80 torr. Because the pressure inside the arteries is low, the pressure outside the arteries can block the arteries and block blood flow. When such a blockage occurs in the coronary arteries, the blood supply to the heart muscle is interrupted, causing the heart to stop functioning.

The validity STEM aspects are analysed in terms of the use of language and STEM component namely Science, Technology, Engineering and Mathematics. The result of validity is showed in the following table

\begin{tabular}{|cccccc|}
\hline Table 8 The validity of STEM Aspect & \multicolumn{2}{c}{ Score } & $\begin{array}{c}\text { Percentage of } \\
\text { Average Score }\end{array}$ & Criteria \\
\hline Assessed components & V-1 & V-2 & & 78 & Valid \\
\hline $\begin{array}{c}\text { STEM Component (Sciences, Technology, } \\
\text { Engineering, Mathematics }\end{array}$ & 12 & 13 & 81 & Valid \\
\hline \begin{tabular}{c} 
The use of language \\
\hline
\end{tabular} & 7 & 6 & & & \\
\hline
\end{tabular}

The result shows that the designed STEM aspects are valid for all components.

The effectiveness of the developed teaching material was analysed using the $\mathrm{N}$ gain value based on pre-test and post-test data. Pre-test data refers to the results of the test instrument assessment before using the teaching material and post-test data refers to the results of test instruments after using the teaching material. The results of the $\mathrm{N}$-gain are shown in the following table. 


\begin{tabular}{ccccc}
\hline Table 9 The result of N-Gain value & & & \\
\hline $\begin{array}{c}\text { Number of } \\
\text { respondents } \\
\text { (students) }\end{array}$ & $\begin{array}{c}\text { The Average } \\
\text { score of Pre-test }\end{array}$ & $\begin{array}{c}\text { The Average } \\
\text { score of pre-test2 }\end{array}$ & $\begin{array}{c}\text { The Average } \\
\text { Value of N-Gain }\end{array}$ & Criteria \\
$\mathrm{N}=40$ & 90.34 & 119.18 & 0.48 & Medium \\
\hline
\end{tabular}

The result shows that the average value of $\mathrm{N}$-Gain is 0,48 representing in medium criteria. This means that the developed teaching material is quite effective as a source learning used for biology student.

Student as user give responds to the developed teaching material and the result can be shown in the following table.

\begin{tabular}{|ccc|}
\hline Table 10 The result of student's respond to the teaching material \\
\hline Assessed Component & The Percentage of Score & Criteria \\
\hline Attracting attentiveness & 89.91 & Highly Strong \\
\hline Material Content & 87.82 & Highly Strong \\
\hline The Use of Language & 88.49 & Highly Strong \\
\hline
\end{tabular}

\section{CONCLUSIONS AND RECOMMENDATIONS}

The teaching material integrating the understanding of physics concept about fluid topic and its application in biology based on Science, Technology, Engineering, and Mathematics (STEM) has been developed. The product has passed validation process consisting of the feasibility of content, the validity of instrument test and from the STEM aspect. For the validation in terms of content of teaching materials consist of the content eligibility, the use of language and the technical appearance/layout give the average percentage 82.95; 78.13; and 81.94 respectively meaning that all assessed components of teaching material are in valid category. In terms of instrument test validation showed that the fifteen questions are valid in highly valid category. And from STEM aspect, all components consisting of Science, Technology, Engineering and Math also from the use of language are valid for all component with the average percentage are 78 and 81 for STEM and the use of language respectively. The result of $\mathrm{N}$ gain showed an increase in scientific literacy by 0.48 due to the use of this teaching material. And from the student response test, it shows that the developed teaching materials are feasible for use as a learning source for students.

\section{REFERENCES}

Akbar, Sa'dun. (2013). Instrumen Perangkat Pembelajaran. Bandung : Rosda Karya. Damayanti, W. and K.F. Perdana, (2016) Penguasaan Konsep Biologi Berbasis Konsep Fisika Menggunakan Pembelajaran Tematik dengan Model Problem Based Learning. Kontemporer Sains, Lingkungan, dan Inovasi Pembelajarannya

Frankel, T., (2011) The geometry of physics: an introduction. : Cambridge university press.

Hake, R. R. (2002). Analyzing Change/Gain Scores. November 2015. http://www.physics. indiana. edu/ sdi/AnalyzingChange-Gain.pdf 
Hilton Huling and Jackie Speake Dwyer, (2018) Designing meaningful STEM Lessons, NSTA Press, Virginia

Keevil, S.F., (2012) Physics and medicine : à historical perspective. The Lancet, 379(9825) : p. 1517-1524. Retrieved from https://doi.org/10.1016/S01406736(11)60282-1

Klymkowsky, M.W., K. Garvin-Doxas, and M. Zeilik, (2003) Bioliteracy and teaching efficacy : what biologists can learn from physicists. Cell Biology Education, 2(3) : p. 155-161. Retrieved from https://doi.org/10.1187/cbe.03-03-0014

Koonin, S.E., (2018) Computational physics : Fortran version. : CRC Press. Retrieved from https://doi.org/10.1201/9780429494024

Maris, P., et al., (2010) Scaling of ab-initio nuclear physics calculations on multicore computer architectures. Procedia Computer Science, 1(1) : p. 97-106. Retrieved from https://doi.org/10.1016/j.procs.2010.04.012

Nicoll, G., (2001) A report of undergraduates' bonding misconceptions. International Journal of Science Education, 23(7) : p. 707-730. Retrieved from https://doi.org/10.1080/09500690010025012

Serway, R.A. and J.W. Jewett, (2018) Physics for scientists and engineers with modern physics. : Cengage learning.

Toto, T. and L. Yulisma, (2017) Analisis Aplikasi Konsep Gaya Dalam Fisika Yang Berkaitan Dengan Bidang Biologi. Jurnal Penelitian Pengembangan Pendidikan Fisika, 3(1) : p. 63-72. Retrieved from https://doi.org/10.21009/1.03109 